\title{
Exploring and Describing Lexical and Grammatical Feature of English Used in Contracts
}

\author{
Supardi \\ Faculty of Law, University of Jember \\ Jember, Indonesia \\ supardi@unej.ac.id \\ ahmardi@yahoo.com
}

\begin{abstract}
As international or global language, English has played its vital role as a means of international communication for many years. Most of people over the world have used it in many international business transactions. In term of legal transactions, for example, English has been used in legal contract. Paying attention to this use of English in contract, it is important for the EFL learners of law students to master contract English (English used in contract), because the knowledge of contract is closely dealt with contract law, a subject that the law students have to take for their study in law faculty. To meet their need to master contract English, it is certainly necessary for the EFL teachers, especially those who are teaching at law faculty, to be able to provide the teaching materials concerning English used in contract. In discussing English used in contract, this paper will firstly address its discussion on an understanding of what contract is. In addition, it explores and describes the lexical and grammatical features of English used in contract. Finally, this paper presents an example of teaching materials developed from such lexical and grammatical features of English used in contract.
\end{abstract}

grammatical

Keywords-contract; $\quad$ contract $\quad$ English; lexical;

\section{INTRODUCTION}

English has spread around the globe so extensively that it is becoming a truly international language [1]. As the international language, on the one hand it means that English has met the definition of international language that is "the language which is used by people of different nations to communicate with one another" [2]. On the other hand, English becomes the internatioal language because it has exemplified most of such four features of an international language [3] as the econocultural function of English, the establishment of bi-/multilingual communities of English use, the use of English as not only an elite lingua franca, but also as a means of empowerment and resistance, and the language change (the spread of English has not been a one-sided process stemming from the center, but has also been driven by African and Asian agency [4]. Because English has met such features of being the international language, many scholars have finally considered it as a truely international language so that it has been used by the people over the world as a means of international communication..

As the language for international communication, English has become a demand of most people over the world for their international communication for many years [5]. To make this statement more clearly, he then explains that those people use this internationally or globally accepted language for such international/global transactions as accounting, aviation, banking, business, education, hospital, law, medicine, nursing science, technology, and many others. English in these various uses is known as English for Specific Purposes (ESP) which emerged in the late 1960s [6]. From this point, these various uses of English certainly give evidence that people use English for many diffferent purposes. In other words, they use English for a variety of contexts.

To be concerned with the use of English in context, this paper concentrates its discussion on English used in the field of law known as legal context. In this legal context, English has also been used in a legal document called contract. Since English is used in this context (contract) or specific purpose, it certainly has its own specifically linguistic features constituting both lexis and grammar. In term of lexis, for example, lawyers tend to use such certain archaic words as aforesaid, herein, notwithstanding, etc. in writing legal contract [7]. In addition, in case of grammar, for the purposes of business contracts, the use of "shall" is only to impose an obligation on the subject of a sentence, in other words, to convey the meaning "has a duty to" [8]. Furthermore these specific lexis and grammar make the language of contract different from that of such other legal documents as opening statements, statutes, deeds, wills, mortgages, police reports, and others. For this, the EFL learners of law students have to know more the language used in contract. 
In order that the EFL learners can easily learn the language of contract, it is important for the EFL teachers to be able to provide teaching materials concerning the language of contract. For this fact, this paper finally aims at exploring and describing the lexical and grammatical features of English used in contract. To be concerned with this aim, this paper firstly overviews an understanding of contract. In addition it addresses its discussion on the use of English in contrract. Finally, the teaching materials developed with the use of English in contract are presented in this paper.

\section{OVERVIEW OF CONTRACT}

In every day life contracts are all around the people. Many of them enter their contracts in their daily activities. For example, everyone makes a promise to his/her family members and friends. In business transactions suppliers and their customers make promises about the supply and acquisition of goods and services In addition, in insurance company the insurance holders pay the insurance and promise to avoid insurance fraud, and in term of a damage or accident the insurance company pays compensation. Almost everything the people do in such business transactions as renting a apartment, buying a house, online shopping, and many others is regulated in contract law. However, not all of these activities are legally binding. Only some of them that are binding are contracts. From these facts, it is therefore necessary to have an appropriate understanding of what contract is.

Scholars have different points of view in understanding the term contract. Some of them have defined it in different ways. Contract is an agreement which the parties intend to be legally binding [7]. In the different words, it is regarded as an agreement which is legally enforceable [9]. Different from these two definitions, it is defined as a promise that the law enforces [10]. Though contract is differently defined, the three definitions lead to the same understanding that contract can be considered as a legally enforceable agreement or promise which binds the contracting parties. Based on these understandings, in contract there are at least two parties who make an obligation to perform or not to perform something, which contains legally enforceable promises.

Paying attention to the definitions of contract above, the two phrases, legally binding and legally enforceable are very important to understand contract. Without these phrases, the words agreement and promise become the common features in society's daily life and they do not have the legality which binds the parties making the agreement (the promise). On the contrary, with these phrases the law will force the parties making the agreement (the promise) to perform the agreement (the promise) or to pay the damages to whom the greement (the promise) was made. In other words, in contract the parties making the agreement (the promise) are legally bound to the contract they have made.

In order that the contract can have legally binding or legally enforceable promises, it has to meet some key ingredients of contract. There are four essential elements of a valid contract [11], which are mentioned as in the followings.

1. Capacity of the parties.

2. Mutual agreement (assent) or meeting of the minds (a valid offer and acceptance).

3. Consideration (something of value given in exchange for a promise).

4. Legality of subject matter.

With these four elements of contract, Emerson then explains that a contract is an enforced rule of society. When a contract has been made, it is as binding upon the parties as any statute or any other law. As a consequence, one party cannot withdraw without additional agreement by the other party or parties.

In order to have more understanding of contract, it is also important to learn it from a sample this legal document. Below is the sample of contract document written in English adapted from https://www.printablecontracts.com/Car_Selling_Contra ct.php.

\section{A. Contract for Purchase of a Car}

$\begin{array}{cc}\text { Buyer's Name } & \text { Seller's Name } \\ \text { Address } & \text { Address } \\ \text { City, State, ZIP } & \text { City, State, ZIP } \\ \text { Phone } & \text { Phone }\end{array}$

The Seller hereby conveys to the Buyer full ownership and title to the motor vehicle described below:

Description of Motor Vehicle Sold:

Year Make Model

VIN:

The Buyer hereby agrees to pay the Seller $\$ \bar{X}$ on

$\mathrm{MM} / \mathrm{DD} / \mathrm{YY}$, and \$Y on the Nth day of each month beginning MM/DD/YY, until all payments made to the Seller total \$X.

If Buyer fails to make a payment on or before its due date, a late fee of $\mathbf{\$ X}$ shall be added to the balance due and shall be payable immediately.

Both parties hereby agree that this is an "as-is" sale, with no warranties of any kind expressed or implied. 
This agreement shall be governed by the laws of the State of and the County of and any applicable U. S. laws.

The parties hereby signify their agreement to the terms above by their signatures affixed below:

\section{Buyer's signature, date Seller's signature, date}

\section{THE USE OF ENGLISH IN CONTRACT}

Up to the present time English has become the primary international language. As the international language it has also played its vital role as a means of the international business transactions. In internationally legal transaction, for example, English is used in a legal document called contract. Concerning the use of English in contract, this section focuses on such two points as lexical features of contract and grammatical features of contract, which are furtherly discussed in the following sub-sections.

\section{A. Lexical features}

Contract is a type of legal documents [12]. Because it belongs to the legal document, English used in contract certainly refers to that used in law which is regarded as Legal English. One of the characteristics of Legal English, which is used in contract, is the use of archaic words [13, 14, and 15]. The archaic words in contract can be seen in the table below.

TABLE 1. ARCHAIC WORDS IN CONTRACT

\begin{tabular}{|c|c|}
\hline $\begin{array}{c}\text { Archaic } \\
\text { Words }\end{array}$ & Meanings \\
\hline hereby & $\begin{array}{c}\text { as a consequence of this agreement/by } \\
\text { this mean/by reason of this }\end{array}$ \\
\hline herein & in this document/in this \\
\hline hereinafter & $\begin{array}{c}\text { from this point onwards in this } \\
\text { document/later in this contract }\end{array}$ \\
\hline hereof & of this \\
\hline hereto & to this contract \\
\hline hereunder & under this \\
\hline thereof & of that \\
\hline thereunder & under that \\
\hline
\end{tabular}

As well as the archaic words, there are many other words which are regarded as lexical features of contract. These words are called contract terminology [14], which is classified into such two points as the terminology referring to the parties making the contract and miscellaneous vocabulary. In term of the terminology referring to the parties, the use of suffix -er/-or and -ee are derivative pairs which frequently occur in contracts, which is indicating the reciprocal relationship between the parties to the contract, such as trainer and trainee, assignor and assignee.

In case of miscellaneous vocabulary, the words which are frequently used in contract can be seen in the table below.

TABLE 2. CONTRACT TERMINOLOGY (MISCELLANEOUS) IN INGELS (2006)

\begin{tabular}{|c|c|}
\hline $\begin{array}{c}\text { Miscelaneous } \\
\text { vocabulary }\end{array}$ & Meanings \\
\hline clause & $\begin{array}{c}\text { part of contract stating a } \\
\text { condition }\end{array}$ \\
\hline term & condition stipulated in a contract \\
\hline persuant to & in accordance with, subject to \\
\hline regardless of & in spite of \\
\hline bind & $\begin{array}{c}\text { legally oblige one, tie one to do } \\
\text { something }\end{array}$ \\
\hline come into effect & to start being valid \\
\hline liable for & responsible for \\
\hline
\end{tabular}

As well as the contract terminology mentioned in the table 2, there are also many other words which are frequently used in contract. They can be adapted from the URL https://www.englishclub.com/businessenglish/vocabulary contracts.htm, In this URL they are called contract vocabulary as mentioned in the table below. 


\section{TABLE 3. CONTRACT VOCABULARY FROM ENGLISHCLUB.COM}

\begin{tabular}{|c|c|}
\hline $\begin{array}{l}\text { Contract } \\
\text { Vocabulary }\end{array}$ & Meanings \\
\hline agreement & $\begin{array}{l}\text { n. an arrangement between two or more } \\
\text { people, contries, etc; contract }\end{array}$ \\
\hline appendix & $\begin{array}{l}\text { n. additional or supplementary material } \\
\text { at end of contract, book, etc. }\end{array}$ \\
\hline arbritration & $\begin{array}{l}\text { n. settlement of a dispute by a person } \\
\text { chosen by both parties. }\end{array}$ \\
\hline article & $\begin{array}{l}\text { n. a particular statement or stipulation } \\
\text { in a contract; clause }\end{array}$ \\
\hline clause & $\begin{array}{l}\text { n. a particular statement or stipulation } \\
\text { in a contract; article }\end{array}$ \\
\hline condition & $\begin{array}{l}\text { n. anything necessary before the } \\
\text { performance of something else }\end{array}$ \\
\hline $\begin{array}{l}\text { force } \\
\text { majeure }\end{array}$ & $\begin{array}{l}\text { superior, power; unforeseeable event } \\
\text { excusing one party from fulfilling } \\
\text { contract }\end{array}$ \\
\hline fufil & $\begin{array}{l}\text { v. to satisfy a condition; to compelete } \\
\text { the required task; to fulfill us }\end{array}$ \\
\hline $\begin{array}{l}\text { null and } \\
\text { void }\end{array}$ & invalid; without legal force; not binding \\
\hline $\begin{array}{l}\text { on the one } \\
\text { hand }\end{array}$ & $\begin{array}{l}\text { on one side }- \text { on the other hand }=\text { on } \\
\text { the other side }\end{array}$ \\
\hline party & $\begin{array}{l}\text { n. the person or persons forming one } \\
\text { side of an agreement }\end{array}$ \\
\hline stipulate & v. to specify as an essential condition \\
\hline terms & n. conditions or stipilations \\
\hline warrant & $\begin{array}{l}\text { v. to give formal assurance; to } \\
\text { guarantee; } \mathbf{n} \text {. warrant = guarantee }\end{array}$ \\
\hline whereas & $\begin{array}{l}\text { conj: it being the case that; in view of } \\
\text { the fact that [introduction to contracts] }\end{array}$ \\
\hline
\end{tabular}

\section{B. Grammatical Features}

The other linguistic feature as the characteristic of contract language is grammatical feature. One of the grammatical features frequently found in contract is long sentence [16]. Regarding the long sentence in contract, the following sentences can be seen as the examples.

(1) Within 30 days after the signing and coming into effect of this contract, the Buyer shall proceed to pay the price for the goods to the Seller by opening an irrevocable $L / C$ for the full amount of USD
30,000 in favor of the Seller through a bank at export port.

(2) Where servants, agents or subcontractors of the Company carry out work under the direction of the Client, the Client shall be fully responsible for, and indemnify and hold harmless the Company against any claim, loss or damage of any kind, whether arising in contract in negligence, in equity or by statute or under any law connected in any way with the Services, Project or relationship established by this Agreement.

Another grammatical feature frequently used in contract is the use of modal verb. In this case, the modal verb "shall" is frequently used in contract, for stipulating rihgts and obligations of the relevant parties $[8,14$, and 16]. As well as the two sentences above which show clearly the use of the modal verb "shall" in contract, the use of this modal verb can also bee seen in the following sentences from the sample of contract above.

(3) If Buyer fails to make a payment on or before its due date, a late fee of $\$ \boldsymbol{X}$ shall be added to the balance due and shall be payable immediately.

(4) This agreement shall be governed by the laws of the State of and the County of and any applicable U. S. laws.

Veiwed from syntactical structure, contract is often formulated in conditional sentences. The use of it is to specifiy conditions and terms because the use of the word "if" in conditional sententence in contract is to introduce a condition [14]. It can be seen in the sentence below.

(5) If the patient refuses to pay his GP after the medical examination, he breaches a contract implied in fact.

As well as the use of "if" conjunction, there are some other alternative ways to state a condition in contract, such as using "unless" which means "if not" and "should + subject + verb". The following sentences written in [14] can be seen as the examples.

(6) We agree that unless we have obtained your prior written consent, we will not disclose information to any third party. 
(7) Unless a written agreement is delivered by both the publisher and the author, neither the publisher nor the author will alter the manuscript.

(8) Should the tenants fail to meet the payment deadlines detailed in clause 7 hereof, the proprietor shall be entitled to damages.

\section{MATERIALS DEVELOPMENTS FOR TEACHING ENGLISH USED IN CONTRACT}

As stated in the title, this paper aims at exploring and describing lexical and grammatical features of English used in contract. For this aim, this sub-sections focuses its discussion on how to develop such two linguistic features found in contract to be materials for teaching and learning. Concerning the lexical features there are varieties of activities that the teachers can use in the classroom. For classroom activities, some useful prepared exercises for vocabulary leaming such as word and meaning matching, labelling sentence completion, crossword puzles, semantic analysis, and completing lexical sets are proposed [17]. As well as these activities, states that teaching vocabulary can constitute the activities of multiple-choice, fill-in, and cloze passages [18].

With the use of the techniques of teaching vocabulary suggested by both Nation and Kilickaya, the lexical features of English used in contract as discussed in the previous subsection can be designed or developed for the teaching materials which are presented in the following samples.

\section{Sample 1}

$$
\begin{array}{cc}
\text { Topic } & \text { : Archaic Words } \\
\text { Activity } & \text { : Matching }
\end{array}
$$

Instruction : Look at the sentences and the phrases the left side, and then match the underlined archaic words to the correct meaning on the right side.

1. The company named above (herinafter referred to as "the contractor")

2. the schedule hereto attached

3. payment of the obligations herein

4. By signing this contract, you hereby accept the terms and conditions.
9f6b5b50c3bd/contracts.html?c=1\&wrk=Wrk 99081979 -9339-1e74-0129-00ee44919397\&k=0

Sample 2

Topic : Contract Vcabualry (Terminology)

Activity : Completion, Fill-in

Instruction: Complete the text below with the words in the box under the text.

A contract is a legal agreement between two or more .....1.... (people or groups). Every contract contains different .....2..... (conditions) which state what each side must do. If the contract is in a written form, and somebody signs it, then usually that person must meet or .....3..... all the conditions, even if he or she has not read the full agreement. We can also say that the conditions are now ...... ......

If someone does not fulfil certain conditions, for example if a person refuses to pay after receiving a service, the other party may decide to .....5..... in a court of law.

Sometimes, the parties may want to include some extra conditions in a contract after it has been signed. They can do this by adding an .....6..... .

$$
\text { appendix binding fulfill parties sue terms }
$$

Adapted from http://www.linguahouse.com/esl-lessonplans/business-english/9e074fbf-1681-7a54-29749f6b5b50c3bd/contracts.html?c=1\&wrk=Wrk_99081979 -9339-1e74-0129-00ee44919397\&k=0

Adapted from http://www.linguahouse.com/esl-lessonplans/business-english/9e074fbf-1681-7a54-2974-

a. as a result b. in this document

c. later in this document d. to this document 


\section{Sample 3}

Topic

Activity

Instruction : Match the types of contract on the left side to their definitions on the right side.

\begin{tabular}{|c|c|}
\hline $\begin{aligned} & \text { 1. } \text { a lease } \\
& \text { 2. an employment } \text { contract } \\
& \text { 3. a contract of } \\
& \text { sale } \\
& \text { 4. an insurance } \\
& \text { policy } \\
& \text { 5. a software } \\
& \text { license } \\
& \text { 6. a credit } \\
& \text { agreement }\end{aligned}$ & $\begin{array}{l}\text { a. a contract between a seller (or } \\
\text { vendor) and a buyer (or } \\
\text { purchaser } \\
\text { b. a contract between an } \\
\text { employer and employee } \\
\text { c. a contract between an } \\
\text { insurance company and a } \\
\text { person who pays for the } \\
\text { insurance } \\
\text { d. a contract which allows one } \\
\text { party (the tenant) to use the } \\
\text { land or property of the other } \\
\text { party (the landlord) for a } \\
\text { specified period of time } \\
\text { e. a software license a contract } \\
\text { which allows someone to } \\
\text { use a computer programme } \\
\text { f. a legal contract in which a } \\
\text { bank agrees to loan a } \\
\text { customer a certain amount of } \\
\text { money for a specified } \\
\text { amount of time }\end{array}$ \\
\hline
\end{tabular}

Adapted from http://www.linguahouse.com/esl-lessonplans/business-english/9e074fbf-1681-7a54-29749f6b5b50c3bd/contracts.html?c=1\&wrk=Wrk 99081979 -9339-1e 74-0129-00ee44919397\&k=0

Regarding the materials development for teaching the grammatical features of English used in contract, some samples adapted from [19] are presented below.

\section{Sample 4}

Topic

Activity

Instruction

\section{: Modal verb "shall"}

: Semantic Analysis

: Read the sentences below carefully. What does the word shall mean in the context of this clause?

a. The buyer shall nominate the date of shipment. The buyer shall give the seller at least two weeks' notice of probable readiness of vessel(s) and of the approximate quantity to be loaded.

b. Upon notification of probable readiness of vessel(s), the seller shall nominate a port for the loading of goods.
Sample 5

Topic : Conditional sentence with If and Unless

Activity : Semantic Analysis

Instruction : Decide which sentences below are found in contract.

a. If the Seller becomes aware that a representation contained in Article 3 is inaccurate, then the Seller shall promptly notify the Buyer thereof.

b. If I have enough time, we'll visit Robert.

c. If you are hungry, I'll make you something to eat.

d. Unless the Seller materially breaches an obligation, the Buyer shall use the Buyer's best efforts to consummate the Transactions.

e. If Acme obtains all necessary consents, it may transfer the Shares.

f. If I fail the exam, I shall take it again.

\section{DISCUSSION}

Language instruction has five important components-students, a teacher, materials, teaching methods, and evaluation [20]. As one of the important components in language instruction, materials may become suitable for students' needs, even if they are not designed specifically for them, that textbooks make it possible for students to review and prepare their lessons, that textbooks are efficient in terms of time and money, and that textbooks can and should allow for adaptation and improvization [21]. To be concerned with the materials for teaching English used in contract, it is found out that there are two main characteristics of contract English, both lexical and grammatical features.

In term of lexical features, tables 1,2, and 3 indicate that the words mentioned in those tables constitute the terminology or vocabulary frequently found in the contractual documents. For this fact, the EFL learners of law students have to master these lexical features to have more understanding of contract.

In case of grammatical features, the contract language has its own syntactical pattern as the main charateristics of contract. The use of long sentences, modal verb "shall", and conditional sentence with the conjunction if and unless are also frequently found in the contractual documents. The sentences 1 to 8 mentioned in the previous sections are the examples of the syntactical patterns frequently used in contract. It is therefore also necessary for the EFL learners of law students to master the grammatical features of English used in contract.

In order the EFL teachers can help their students master those lexical and grammatical features of English 
used in contract, this paper proposes some samples of materials designed for teaching contract English. Samples 1 to 5 mentioned above can certainly become an alternative for classroom activities.

\section{CONCLUSION}

As the primary international language, English has played its vital role as a means for communication in internationally legal business transaction for many years. In this transaction, it has been used in a legal document called contract. Because of its use in contract, English has its own specific linguistic features, both lexically and grammatically. In terms of the lexical features, archaic words and technical terms (contract terminology/vocabulary) become one of the characteristics of contract English. As well as the lexical features, the grammatical features also constitute the other characteristic of English used in contract. As a result, due to the use of both specific lexis and specific grammar, contract English has its own different linguistic features from those of General English and such other English for Specific Purposes as Accounting English, Banking English, Medical English, Nursing English, and many others. Concerning the use of English in contract, it is therefore necessary for the EFL learners of law students to learn this contract English and for the EFL teachers to develop the teaching materials regarding English used in contract.

\section{Reference}

[1] Crystal, D. English as a global language. Cambridge: Cambridge University Press. 1997.

[2] Smith, L. English as an international auxiliary language. RELC Journal, 7(2), 38-42. 1976.

[3] McKay, Sandra, L. Teaching English as an international language: the role of culture in Asian contexts. The Journal of Asia TEFL, 1(1), 1-22. 2004.

[4] Brutt-Griffler, J. World Englishes: a study of its development. Clevedon: Multilingual Matters. 2002.

[5] Supardi. ESP (English for specific purposes): teaching legal English using lexical approach. The fourth international seminar on English language and teaching (ISELT-4) 2016 Proceedings, ISBN 978-602-74437-0-9, pp. 346-354.

[6] Hutchinson, T. \& Waters, A. English for specific purpose: a learning-centered approach. Cambridge: Cambridge University Press, 1987.
[7] Thorpe, C.P \& Bailey, J.C.L. Commercial contracts: a practical guide to deals, contracts, agreement and promises. London: Kogan Page Limited. 1999.

[8] Adams, Kenneth. A. Making Sense of 'Shall'. New York Law Journal. October 18, 2007. Retrieved on 24 March 2017 from http://adamsdrafting.com/downloads/nylj-shall101807.pdf,

[9] Boundy, C. Business Contract Handbook. USA: Gower Publishing Limited. 2010.

[10] Blond, Neil. C. Contracts. New York: Aspen Publishers. 2009.

[11] Emerson, Robert, W. Business Law. New York: Barron's Educational Series, Inc. 2009.

[12] Cummins, Robert, R. Basics of Legal Document Preparation. USA, New York: Delmar Publishers, Inc. 1997.

[13] Crystal, D. \& Davy, D. Investigating English Style. London: Longman Group Limited. 1969.

[14] Ingels, M. Legal English Communication Skills. Leuven (Belgie): Acco. 2006.

[15] Zhang, G. A Comparative Analysis of Lexical Features of Contract English. International Journal on Studies in English Language and Literature (IJSELL) Volume 2, Issue 9, September 2014, pp. 56-64.

[16] Chen Y. \& Yun, D. On the Language Features of English Contract Translation. International Journal of Language and Linguistics. Special Issue: The Sociolinguistics of a Changing World. Vol. 2, No. 6-2, 2014, pp. 1-5.

[17] Nation, P. "Teaching Vocabulary." The Asian EFL Journal Volume 7 Issue 3, (2005): 47-54.

[18] Kilickaya, F \& Krajka, J. "Teacher's Technolory Use in Vocabulary Teaching." Academic Exchange Quorterly Spring (2010): 81-86.

[19] Krois-Lindner, A. \& Firth, M. Introduction to international legal English. Cambridge: Cambridge University Press. 2008.

[20] Kitao, K. \& Kitao, S. K. Selecting and developing teaching/learning materials. The Internet TESL Journal, Vol. IV, No. 4, April 1997.

[21] O'Neill, R. Why use textbooks? In R. Rossner and R. Bolitho, (Eds.), Currents in language teaching. Oxford: Oxford University Press. 1990.

\section{Internet}

http://www.linguahouse.com/esl-lesson-plans/businessenglish/9e074fbf-1681-7a54-2974-

9f6b5b50c3bd/contracts.html?c=1\&wrk=Wrk_99081979 -9339-1e74-0129-00ee44919397\&k=0. Retrieved on 20 March 2017. 
https://www.englishclub.com/business-

english/vocabulary_contracts.htm. Retrieved on 20

March 2017.

https://www.printablecontracts.com/Car_Selling_Contra

ct.php. Retrieved on 20 March 20170 